\title{
Implementasi Perda No 09 Tahun 2014 Tentang Pengelolaan Pasar Rakyat, Pusat Perbelanjaan Dan Toko Swalayan Di Kota Pekanbaru (Studi Kasus: Indomaret Dan Alfamart)
}

\author{
${ }^{1}$ Yupi Sasmita Dewi, ${ }^{2}$ Zaili Rusli, ${ }^{3}$ Adianto \\ ${ }^{123}$ Pascasarjana Ilmu Administrasi Universitas Riau \\ e-mail :yupisikumbang96@gmail.com
}

\begin{abstract}
Abstrak
Tujuan dari penelitian ini adalah untuk mengetahui Implementasi Kebijakan Peraturan Daerah No.09 tahun 2014 tentang Pengelolaan Pasar Rakyat, Pusat Perbelanjaan dan Toko Swalayan di kota Pekanbaru dan Faktor-faktor yang mempengaruhinya. Penelitian ini menggunakan metode deskriptif kualitatif. Sedangkan teknik pengumpulan data dilakukan dengan observasi, studi dokumen dan wawancara mendalam dengan informan, penentuan informan dilakukan dengan teknik purposive sampling. Berdasarkan hasil penelitian menunjukan bahwa : Inefektifitas penegakan perda dipengaruhi oleh beberapa faktor antara lain: substansi hukum dan ketidaktegasan Dinas Perindustrian dan Perdagangan dalam menjatuhkan sanksi terhadap pelanggaran yang dilakukan oleh pelaku usaha minimarket dan budaya hukum pengusaha minimarket yang menganggap prosedur mengurus IUTM sangat rumit dan memerlukan jangka waktu lama.
\end{abstract}

Kata kunci : Implementasi, Kebijakan, Peraturan Daerah

\begin{abstract}
The purpose of this research is to know the implementation of Regional Regulation No 09 of 2014 on the Management of Public Markets, Shopping Centers and Supermarkets in Pekanbaru and the factors that influence it. This research used descriptive qualitative method. Technique of collecting data through interview technique, observation and documentation by using purposive sampling method in informant selection. The results show that the effectiveness of local regulation enforcement is influenced by several factors, including: legal substance and indecisiveness of the Department of Industry and Trade in imposing sanctions on violations committed by minimarket business actors and the legal culture of minimarket entrepreneurs who consider the procedure for managing IUTM to be very complicated and takes a long time.
\end{abstract}

Keywords: Implementation, Policy, Regional Regulations

\section{PENDAHULUAN}

Kota Pekanbaru merupakan Ibu Kota Provinsi Riau yang juga diberi hak otonomi daerah untuk mengatur rumah tangganya sendiri. Berdasarkan catatan Badan Pusat Statistik (BPS) Provinsi Riau, IPM (Indeks Pembangunan Manusia) / Human Development Index (HDI) tertinggi di Riau berada pada Kota Pekanbaru sebesar 80,66 poin.Jumlah penduduk kota Pekanbaru saat ini berjumlah 1,1 juta jiwa dengan komposisi 54,25\% berpendidikan SLTA keatas (pada tahun 2014 income perkapita $\$ 67.000$, kondisi seperti ini adalah pasar yang empuk bagi investor untuk berinvestasi karena baiknya tingkat perekonomian suatu masyarakat.

Selain itu, letak kota Pekanbaru yang sangat strategis terletak di simpul jalur perhubungan darat lintas sumatera dan menjadi pintu gerbang bagi Indonesia bagian Barat dalam keluar masuknya perdagangan Internasional terlebih dengan berlakunya Masyarakat Ekonomi Asia (MEA) menjadi keunggulan geografis yang dimanfaatkan kota Pekanbaru menjadi lumbung-lumbung pendapatan bagi kas daerah dengan melakukan pembangunan pada sektor perdagangan, pusat bisnis, dan jasa. 
Pada sektor perdagangan, salah satu bentuk usaha yang saat ini mulai marak bermunculan yaitu pengembangan bisnis waralaba/ritel dalam bentuk toko modern berizin. Pengertian toko modern menurut Pasal 1 angka 8 pada Perda No 09 Tahun 2014 adalah toko dengan sistem pelayanan mandiri, menjual berbagai jenis barang secara eceran yang berbentuk Minimarket, Supermarket, Department Store, Hypermarket ataupun grosir yang berbentuk Perkulakan. Secara umum di Indonesia bentuk dari ritel toko modern yaitu supermarket, hypermarket, minimarket, department store, dan bookstore. Berdasarkan data dari AC Nielsen, pertumbuhan ritel modern setiap tahunnya berkisar pada angka $10 \%$ hingga $30 \%$ yang ditunjukkan dengan ekspansi ritel modern sangat agresif hingga memasuki wilayah pemukiman penduduk. (Positioning Paper Ritel KPPU,2008)

Pada saat ini terdapat berbagai macam bentuk dari toko modern, yang dinilai melakukan ekspansi cukup tinggi di Indonesia yaitu ritel Alfamart dan Indomaret. Berkembangnya jumlah gerai ritel tersebut ditunjukkan dalam data yang dilansir oleh databoks.co.id bahwa Alfamart dalam tiga bulan pertama hingga tahun 2019 telah menambah 47 gerai baru dengan total gerai menjadi 13.726 gerai. Sementara toko ritel modern Indomaret telah membuka sekitar 534 gerai baru di tahun 2019 dengan total keseluruhan gerai 16.900 gerai yang tersebar diseluruh Indonesia.

\section{Gambar 1.1Pertumbuhan jumlah gerai Indomaret dan Alfamart di Indonesia Tahun 2019}

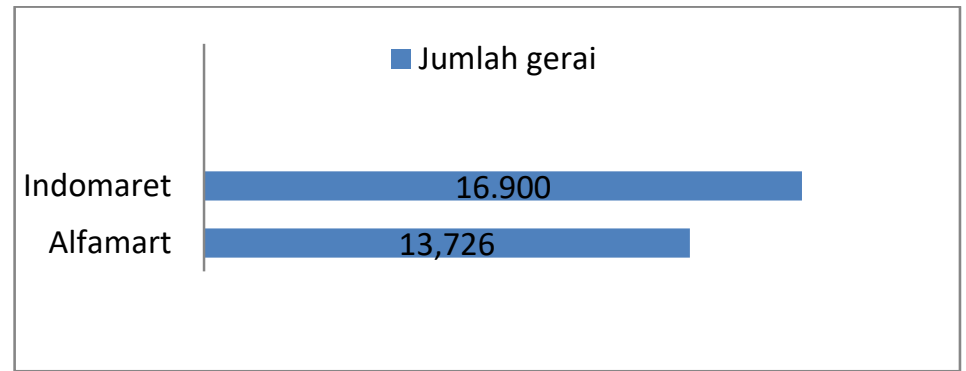

Sumber : Databoks.co.id

Data tersebut menunjukkan bahwa minimarket seperti Alfamart dan Indomaret mengalami pertumbuhan dengan jumlah gerai yang cukup fantastis. Sebagaimana dapat dilihat saat ini dengan mudah ditemui sejumlah toko modern atau minimarket yang berdiri di daerah-daerah bahkan di dalam perkampungan dan pemukiman warga yang menjual barang kebutuhan sehari-hari seperti apa yang diperjualbelikan pada pasar tradisional atau toko kelontong barang harian.

Sebagai kota perdagangan, Kota Pekanbaru juga tentu tidak terlepas dari maraknya pendirian toko modern. Keberadaan toko ritel modern di Kota Pekanbaru menjadi peluang sekaligus ancaman bagi Pemerintah Kota Pekanbaru.Peluang yang dimaksud, keberadaan toko ritel modern memberikan kontribusi pajak daerah yang diperoleh dan penyerapan tenaga kerja.Namun, yang menjadi ancaman bagi Pemerintah Kota Pekanbaru yaitu keberadaan toko ritel modern mampu mematikan usaha pedagang kecil seperti toko kelontong atau bahkan menjadikan pasar tradisional sepi peminat.

Pertumbuhan ekonomi memang semakin maju dengan tumbuh dan berkembangnya toko modern ini, namun pertumbuhan ekonomi juga harus memperhatikan kesejahteraan, pemerataan yang berkeadilan sehingga sudah seharusnya pemerintah perlu melakukan penyelarasan antara toko modern dengan pedagang kecil seperti toko kelontong dan pasar tardisional.Kondisi inilah yang kemudian membuat Pemerintah Kota Pekanbaru merasa harus membuat suatu kebijakan dalam rangka melakukan penertiban dan pengelolaan pasar tradisional dan toko modern lebih lanjut.

Pemerintah Kota Pekanbaru kemudian mengeluarkan Peraturan Daerah Kota Pekanbaru Nomor 9 Tahun 2014 tentang pengelolaan pasar rakyat, pusat perbelanjaan dan toko swalayan. Peraturan daerah 
tersebut bertujuan untuk melindungi keberadaan pasar rakyat dan jenis usaha mikro, kecil dan menengah sejenis, membangun kerjasama kemitraan antara pasar rakyat, pusat perbelanjaan dan toko swalayan dengan usaha mikro, kecil dan menengah sejenis dalam rangka pemberdayaan pasar rakyat dan jenis usaha mikro, kecil dan menengah sejenis lainnya, mensinergikan usaha ekonomi pasar rakyat dengan toko swalayan sehingga dapat meningkatkan kesejahteraan rakyat.

Meski Peraturan Daerah Kota Pekanbaru Nomor 9 Tahun 2014 telah disahkan dan diimplementasikan, tidak lantas kemudian keberadaan toko swalayan di Kota Pekanbaru menjadi tertib dan berjalan sesuai dengan aturan berlaku.

Tabel 1.1

Jumlah Toko Modern Indomaret dan Alfamart di kota Pekanbaru Tahun 2019

\begin{tabular}{lll}
\hline NO & NAMA TOKO MODERN & JUMLAH \\
\hline 1. & Indomaret & 228 Gerai \\
\hline 2. & Alfamart & 147 Gerai \\
\hline & JUMLAH & 375 Gerai \\
\hline
\end{tabular}

Sumber :Dinas Perindustrian dan Perdagangan Kota Pekanbaru

Berdasarkan data diatas dapat kita ketahui jumlah Indomaret dan Alfamart yang telah berdiri di Kota Pekanbaru melalui data dari Dinas Perindustrian dan Perdagangan Kota Pekanbaru hingga per tahun 2019 ini telah berjumlah total 375 gerai dengan rincian 228 gerai Indomaret dan 147 gerai Alfamart yang tersebar di 12 Kecamatan yang ada di Kota Pekanbaru. Ini kemudian bertolak belakang dengan Peraturan yang ada, Sebagaimana yang terdapat dalam Pasal 46 ayat (1) hanya boleh mengeluarkan izin untuk Alfamart dan Indomaret masing-masing 100 gerai.

Namun pada tahun 2015 Walikota Pekanbaru memberikan penambahan kuota dengan bersedia memberikan izin prinsip pendirian Indomaret dan Alamart masing-masing yakni 150 gerai, dengan alasan untuk meningkatkan Pendapatan Asli Daerah (PAD) dan dalam rangka persiapan untuk mengahadapi gelombang MEA (Masyarakat Ekonomi Asean).

Penambahan jumlah kuota gerai ini mengundang kontroversi antar aktor pembuat kebijakan, karena dianggap menimbulkan bias kebijakan karena jumlah kuota gerai yang diatur berbeda antara Perda dan yang diputuskan oleh Walikota. DPRD Kota Pekanbaru menganggap Walikota Pekanbaru tidak konsekuen dengan kesepakatan yang telah bersama-sama ditetapkan mengenai kuota jumlah toko swalayan modern pada Peraturan Daerah Nomor 09 Tahun 2014.

Pasca terbitnya Perda tersebut 4 tahun berjalan tidak terlihat kondisi dampak dari Imlementasi Perda tersebut yang signifikan terjadi. Ditambah lagi dengan permasalahan bias kebijakan soal aturan jumlah Toko Swalayan Modern yang ditetapkan. Hingga tahun 2019 menurut data dari Dinas Perindustrian dan Perdagangan Kota Pekanbaru tercatat sudah berdiri total sudah mencapai 375 gerai Indomaret dan Alfamart yang tersebar di

Penambahan kuota yang dikeluarkan melalui keputusan walikota Pekanbaru mengakibatkan ekspansi yang dilakukan toko ritel modern Alfamart dan Indomaret semakin tinggi dan terus meningkat secara signifikan tiap tahunnya.Bahkan yang menjadi prihatin adalah jumlah perkembangannya hingga tahun 2019 ini telah melewati batas dari kuota yang diputuskan walikota sebelumnya.

Kebijakan yang dikeluarkan walikota Pekanbaru dengan dalih untuk mendapatkan Pendapatan Asli Daerah (PAD) yang besar dari sektor perdagangan bukanlah sebuah jawaban karena PAD yang disetorkan Alfamart dan Indomaret tidak sebanding dengan redupnya eksistensi pasar tradisional dan matinya ekonomi kerakyatan yang kemudian berakibat pula banyaknya pedagang kecil mengalami kerugian dan menurun omsetnya karena diakibatkan maraknya toko modern Indomaret dan Alfamart tersebar.

Pemerintah kota Pekanbaru sesuai dengan kewenangannya dalam pelaksanaan otonomi daerah mengeluarkan kebijakan daerah sesuai dengan prinsip otda yakni untuk memberi pelayanan, peningkatan 
peran serta, prakarsa, dan pemberdayaan masyarakat yang bertujuan pada peningkatan kesejahteraan rakyat. Seharusnya kebijakan yang dikeluarkan dapat melakukan pengaturan tentang pengembangan dan penataan yang setara berkeadilan terhadap maraknya pendirian supermarket, pasar, swalayan, minimarket khususnya fenomena seperti Indomaret dan Alfamart sehingga mampu membagi secara berkeadilan bagi ekonomi kerakyatan dan ruang hidup bagi pedagang kecil di pasar tradisional atau pedagang kategori Usaha Kecil Mikro Menengah.

Fenomena tentang keberadaan toko modern Alamart dan Indomaret yang tersebar di berbagai sudut kota Pekanbaru menuai beberapa kecaman dan kritikan dari semua kalangan. Di tengah penertiban PKL yang mendapat sorotan negatif untuk Pemerintah Kota Pekanbaru, izin toko modern Alfamart dan Indomaret justru seakan mendapatkan perlakukan istimewa.Keberadaan Alfamart dan Indomaret dituding beberapa pihak tidak melakukan kajian ekonomi yang berdampak terhadap kelayakan sosial terlebih dahulu, karena pada kenyataanya di lapangan dapat dilihat mudahnya ditemui toko Indomaret dan Alfamart karena gerainya yang tersebar diberbagai titik, hingga jam operasional yang memakai 24 jam.

Sebagaimana yang disebutkan pada Pasal 21 ayat (1) dan (2) Perda No 09 Tahun 2014 bahwa Pendirian Pusat Perbelanjaan dan Toko Swalayan wajib memenuhi ketentuan sebagai berikut:

a. Memperhatikan keberadaan Pasar Rakyat, Usaha Kecil dan Usaha Menengah yang ada di wilayah yang bersangkutan dengan membuat kajian kondisi sosial ekonomi masyarakat yang dilakukan oleh lembaga independent yang berwenang;

b. Memperhatikan jarak antara Pusat Perbelanjaan dan Toko Swalayan dengan Pasar Rakyat;

c. Ketentuan jarak sebagaimana dimaksud pada ayat (1) huruf b antara Pusat Perbelanjaan dan Toko Swalayan dengan Pasar Rakyat minimal radius 350 (tiga ratus lima puluh) meter.

Sementara pada Pasal 24 ayat (1) disebutkan mengenai pengaturan jam operasional Toko Swalayan Modern sebagai berikut :

a. untuk hari Senin sampai dengan Jumat, pukul 10.00 wib sampai dengan pukul 22.00 wib; dan

b. untuk hari Sabtu dan Minggu, pukul 10.00 wib sampai dengan pukul 23.00 wib.

Implementasi menyangkut tindakan seberapa jauh arah yang telah diprogramkan itu benar-benar memuaskan.Kemudian menurut Ripley (1985) implementasi merupakan suatu tahapan diantara pembuatan kebijakan dan konsekuensi dari kebijakan. Dimana ia menempatkan implementasi pada tahap ketiga dalam proses kebijakan. Tahap pertama penyusunan agenda, tahap ketiga implementasi kebijakan dan tahap keempat dampak dari kebijakan. Selanjutnya beliau menegaskan bahwa implementasi yang berhasil tidak hanya diukur melalui:

1. Tingkat Kepatuhan Birokrasi

2. Tingkat Kelancaran Rutinitas

3. Dampak Keberhasilan Program

Berdasarkan latar belakang, penulis membahas masalah ini ke dalam sebuah judul penelitian yakni Implementasi Peraturan Daerah Nomor 09 Tahun 2014 Tentang Pengelolaan Pasar Rakyat, Pusat Perbelanjaan Dan Toko Swalayan Di Kota Pekanbaru (Studi Kasus di Indomaret Dan Alfamart). Tujuan penelitian ini untuk Menjelaskan implementasi Kebijakan Peraturan Daerah No.09 tahun 2014 di kotaPekanbaru dan Faktor-faktor yang mempengaruhinya. Manfaat penelitian dapat menjadi tambahan referensi atau acuan bagi pihak lain dan sebagai bahan penelitian selanjutnya untuk mengembangkan dan menyempurnakan penelitian ini. 


\section{METODE}

Jenis penelitian adalah deskriptif kualitatif yaitu penelitian dengan gambaran, atau deskripsi secara faktual dan akurat mengenai fakta-fakta, sifat-sifat serta hubungan antar fenomena yang di selidiki.Penelitian ini dilakukan di Dinas Perdagangan dan Perindustrian Kota Pekanbaru Jl. Teratai No. 83 Kota Pekanbaru dengan informan penelitian terdiri dari informan kunci dan informan pendukung.Jenis dan sumber data yang digunakan adalah data primer yakni data yang diperoleh berupa dari hasil wawancara dengan informan yang langsung dan observasi di lapangan dan menggunakan data sekunder yakni data yang diperoleh dari luar berupa kata-kata atau tindakan orang-orang yang diamati ketika penelitian berlangsung.Teknik pengumpulan data yan digunakan yakni wawancara, observasi, dan dokumentasi.Sedangkan teknik analisis data yang digunakan dalam penelitian ini adalah teknik analisis data di lapangan model Miles dan Huberman yaitu meliputi aktivitas pengumpulan data, data reduction (reduksi data), data display (penyajian data), dan conclusion drawing atau penarikan kesimpulan/verifikasi.

\section{HASIL DAN PEMBAHASAN}

\subsection{Implementasi Peraturan Daerah Kota Pekanbaru Nomor 9 Tahun 2014 dinilai dari Variabel Tingkat Kepatuhan Kelompok Sasaran}

Keberhasilan pelaksanaan suatu kebijakan dinilai dari Indikator pertama yakni Tingkat kepatuhan kelompok sasaran. Untuk menilai dan mengukur indikator pertama berdasarkan teori Ripley dan Franklin peneliti didasarkan pada fakta yang ditemukan dilapangan meliputi sub indikator sebagai berikut:

\section{A. Kebijakan Perizinan}

Kebijakan perizinan merupakan suatu Kegiatan pemberian izin yang dilakukan Pemerintah Kota Pekanbaru kepada pelaku usaha toko modern atau penerbitan Izin Usaha Toko Modern (IUTM).Dalam penerbitan IUTM, Pemerintah Kota Pekanbaru berpedoman pada Peraturan Daerah Nomor 09 Tahun 2014 Tentang Pengelolaan Pasar Rakyat, Pusat Perbelanjaan dan Toko Swalayan.

Dalam Pasal 47 ayat (1) menyebutkan "Pelaku usaha yang melakukan kegiatan usaha dibidang Pasar Tradisional, Pusat Perbelanjaan dan Toko Modern wajib memiliki izin usaha sebagai legalitas. Sedangkan pada ayat (2) izin usaha sebagaimana dimaksud pada ayat (1) terdiri dari :

1. IUPPR untuk Pasar Rakyat

2. IUPP untuk Pusat Perbelanjaan

3. IUTM untuk Toko Modern

Izin usaha dimaksud bertujuan melakukan control terhadap pertumbuhan usaha ritel agar dapat dikendalikan. Namun dalam pemberian izin pelaku usaha Pemerintah Kota Pekanbaru memiliki Peraturan Daerah Nomor 12 Tahun 2012 tentang Retribusi Gangguan atas digantinya Peraturan Daerah Nomor 07 Tahun 2000 tentang Izin Tempat Usaha.

Adapun dalam proses pendirian toko modern terdapat 2 Instansi yang terlibat langsung dalam penerbitan izin yakni Dinas Perindustrian dan Perdagangan (Disperindag) sebagai Dinas yang mengeluarkan surat rekomendasi sebelum diterbitkannya IUTM (Izin Usaha Toko Modern) selanjutnya Dinas Penanaman Modal dan Pelayanan Terpadu Satu Pintu (DPMPTSP) yang berperan sebagai instansi yang melakukan survei dan peninjauan lapangan untuk menilai kelayakan sebelum rekomendasi dari Disperindag dikeluarkan dan sebagai instansi resmi yang menerbitkan surat izin IUTM.

Dalam pelaksanaan pemberian izin usaha Pemerintah menyebutkan setiap pelaku usaha harus mendapatkan persetujuan dari masyarakat, RT/RW, Lurah dan Camat setempat. Namun dalam pelaksanaannya pelaku usaha toko modern banyak melakukan pelanggaran, salah satunya pelaku usaha toko 
modern mendirikan usaha terlebih dahulu baru meminta izin persetujuan dengan warga setempat malahan ada yang tidak meminta izin sama sekali. Seharusnya mengurus IUTS baru mendirikan usahanya.

Dalam proses pembuatan izin operasional usaha bagi pelaku usaha toko modern Pemerintahan Kota Pekanbaru telah diniali optimal dan melaksanakan prosedur sesuai dengan Peraturan Daerah Kota Pekanbaru No 09 Tahun 2014, namun disisi lain penyimpangan tetap terjadi dikarenakan kurangnya kesadaran pelaku usaha dalam menaati peraturan yang ada dengan alasan memangkas prosedur yang dinilai terlalu panjang dan berbelit-belit sebagai syarat wajib sebelum pendirian sebuah toko modern dan ketidakpahaman masyarakat mengenai perda yang ada tentang alur pendirian toko modern.

Selanjutnya peraturan tentang jumlah kuota perizinan terdapat dalam Pasal 46 ayat (1) Perda Kota Pekanbaru No 09 Tahun 2014 berbunyi : "Pelaku usaha dapat mendirikan outlet/gerai Toko Swalayan yang dimiliki dan dikelola sendiri (company ownet outlet) paling banyak 100 (seratus) outlet/gerai."

Sesuai pernyataan pada pasal 46 Ayat (1) diatas, bahwa izin usaha toko modern hanya diperbolehkan masing-masing 100 gerai per nama usaha. Dalam hal ini dijelaskan lebih lanjut yang dimaksud adalah 100 izin usaha untuk toko modern Indomaret dan 100 izin usaha untuk toko modern Alfamart. Namun kenyataan di lapangan setelah peneliti melakukan konfirmasi langsung kepada Disperindag, berdasarkan pencatatan yang mereka miliki bahwa data yang sudah berdiri melampaui jumlah yang ditetapkan dalam perda tersebut, yakni total sudah mencapai 375 toko modern Indomaret dan Alfamart yang berdiri di kota Pekanbaru berdasarkan data untuk sampai tahun 2019.

Kesimpulan peneliti bahwa dalam pendirian toko modern Indomaret dan Alfamart dilihat dari Kebijakan Perizinan belum sesuai dengan Perda No 09 Tahun 2014 yakni untuk sub indikator Kebijakan Perizinan, dikarenakan substansi antar pasal yang mengatur soal perizinan terlalu luas dan tidak mengatur secara jelas sehingga memberikan celah untuk terjadinya mal adminitrasi/penyimpangan di lapangan dan mendukung berkembangnya secara ekspansial berdirinya toko modern di kota Pekanbaru. Selain itu kurangnya komitmen antar instansi dalam penerbitan izin dalam membatasi jumlah toko modern yang ada di kota pekanbaru dengan alasan mendukung pertumbuhan ekonomi daerah kota Pekanbaru juga turut mempengaruhi. Analisa ini didasarkan pada data dan kutipan wawancara yang didapatkan peneliti dengan key Informan yang ada.

\section{B. Kebijakan Zonasi}

Dalam proses pendirian dan pemberian izin terdapat kebijakan zonasi yang harus diperhatikan dan dipatuhi oleh pelaku usaha toko modern. Peraturan zonasi adalah ketentuan Pemerintah Daerah yang mengatur pemanfaatan ruang dan unsur pengendalian yang disusun untuk setiap zona peruntukan sesuai dengan rencana umum tata ruang dan rencana detail tata ruang.

Dalam pendirian dan pemberian izin usaha toko modern, Pemerintah Kota Pekanbaru berpedoman pada Peraturan Daerah Nomor 09 Tahun 2014 tentang Pengelolaan Pasar Rakyat, Pusat Perbelanjaan dan Toko Swalayan, yang didalamnya terdapat kebijakan yang mengatur zonasi toko modern yaitu Pasal 21 ayat (1) yang berbunyi: "Pendirian pusat perbelanjaan dan toko modern wajib memenuhi ketentuan yaitu memperhatikan keberadaan pasar rakyat, usaha kecil, dan usaha menengah yang ada di wilayah yang bersangkutan serta memperhatikan jarak antara pusat perbelanjaan dan toko modern dengan pasar rakyat". Ketentuan jarak sebagaimana yang dimaksud pada ayat (1) antara pusat perbelanjaan dan toko modern dengan pasar rakyat minimal radius 350m (tiga ratus lima puluh) meter. Kemudian kebijakan zonasi disajikan mengenai pertama memperhatikan jarak antara usaha toko modern dengan pasar tradisional yang ada sebelumnya dan kedua yaitu memperhatikan Kondisi Sosial Ekonomi Masyarakat, Keberadaan Pasar Tradisional, Usaha Kecil dan Usaha Menengah yang ada di wilayah bersangkutan.

Sementara fenomena lain peneliti temukan toko modern Indomaret yang berdiri di Jl. Hangtuah hanya berjarak kurang dari $200 \mathrm{~m}$ (dua ratus meter) dari Pasar tradisional Sail yang kemudian juga bersebelahan dengan toko kelontong grosir telur dan beras. Begitu juga toko modern Indomaret yang berada 
di Jl. HR.Soebrantas Panam yang berhadapan langsung dengan Pasar Panam dan toko modern Alfamart yang terletak di Jl. Soekarno Hatta yang berseberangan dengan Pasar Pagi Arengka.

Dari observasi peneliti di lapangan dapat disimpulkan bahwa kebijakan zonasi masih belum sesuai dengan Peraturan Daerah Kota Pekanbaru No 09 Tahun 2014, semestinya dalam pendirian usaha toko modern para pelaku usaha wajib memperhatikan jarak antara pasar tradisional dan pedagang kecil disekitarnya, namun dalam kenyataanya masih banyak ditemukan toko modern yang jaraknya tidak jauh dari pasar tradisional bahkan bersebelahan dengan pedagang toko kelontong/UMKM dan sejenisnya bahkan untuk pengaturan zonasi tidak dilakukan survey secara langsung oleh dinas terkait untuk memastikan kesetujuan pedagang sekitar terkait berdirinya toko modern.

\section{Kebijakan Waktu Operasional}

Dalam pendirian usaha toko modern, terdapat peraturan yang mengatur tentang pembatasan waktu operasional toko modern/swalayan yang telah disebutkan dalam Peraturan Daerah Nomor 09 Tahun 2014 Tentang Pengelolaan Pasar Rakyat, Pusat Perbelanjaan dan Toko Swalayan Pasal 24 ayat (1) yang berbunyi: "Jam kerja Pusat Perbelanjaan dan Toko Swalayan adalah sebagai berikut:(a) untuk hari Senin sampai dengan Jumat, pukul 10.00 wib sampaidengan pukul 22.00 wib; dan (b) untuk hari Sabtu dan Minggu, pukul 10.00 wib sampai dengan pukul 23.00 wib”.

Berdasarkan hasil observasi peneliti di lapangan bahwa masih terdapat toko modern yang memberlakukan jam operasional toko tidak sesuai dengan yang diatur didalam perda, antara lain toko indomaret yang beralamat di Jl. Hr Soebrantas kel. Tuah Karya dan Jl. Ronggowarsito Kec.sail yang masih terpantau buka pada jam 01.30 Wib dan toko modern Indomaret di Jl. Beringin Kec. Sail yang bahkan beroperasi 24 jam. Sehingga dapat disimpulkan implementasi perda dinilai dari kebijakan waktu operasional tidak berjalan optimal/tidak sesuai dengan yang diharapkan pada tujuan perda.

Berdasarkan uraian diatas, dapat disimpulkan bahwa untuk indikator Tingkat Kepatuhan Kelompok Sasaran masih belum berjalan optimal karena dinilai dari 3 sub indikator yang ada yakni kebijakan perizinan, kebijakan zonasi dan kebijakan waktu operasional masih terdapat toko modern yang belum menerapkan kebijakan-kebijakan tersebut sesuai dengan yang diatur didalam Perda No 09 Tahun 2014 tentang Pengelolaan Pasar Rakyat, Pusat Perbelanjaan Dan Toko Swalayan.

\subsection{Implementasi Peraturan Daerah Kota Pekanbaru Nomor 9 Tahun 2014 dinilai dari Variabel Tingkat Kelancaran Rutinitas}

Keberhasilan pelaksanaan suatu kebijakan dinilai dari Indikator kedua yakni Tingkat Kelancaran Rutinitas. Untuk menilai dan mengukur indikator kedua berdasarkan teori Ripley dan Franklin peneliti didasarkan pada fakta yang ditemukan dilapangan meliputi sub indikator sebagai berikut:

\section{A. Pelaksanaan Pengawasan}

Pelaksanaan pengawasan terhadap kelompok sasaran dalam implementasi Peraturan Daerah Kota Pekanbaru No 09 Tahun 2014 dalam hal ini adalah Toko Modern Indomaret dan Alfamart didasarkan pada penilaian jumlah pengawas, dan intensitas/ jadwal pengawasan. Sebagaimana dijelaskan pada pasal 1 poin 13 bahwa Pengawasan adalah upaya yang dilakukan oleh Pemerintah Daerah untukmengawasi keberadaan Pasar Rakyat dan pendirian Pusat Perbelanjaandan Toko Swalayan. Tindakan pengawasan yang dimaksud adalah terkait dengan pengaturan zonasi, pengaturan waktu operasional dan pelaksanaan perizinan.

Dalam hal ini, yang bertugas mengawasi ke lapangan adalah Dinas Perindustrian dan Perdagangan spesifikasi pada bidang tertib perdagangan. Pengawasan fase pertama dilakukan yakni setelah pelaku mendaftarkan nama tokonya (Indomaret dan Alfamart), maka Disperindag melakukan pemeriksaan untuk mendata apakah toko yang telah berdiri sudah legal dan memiliki surat izin/IUTM atau tidak sekaligus melakukan penilaian apakah toko tersebut sudah sesuai standar pendirian sebuah toko modern/swalayan 
sesuai dengan yang ditetapkan di Perda Kota Pekanbaru No 09 Tahun 2014 atau tidak.

Dari hasil penelitian pada Dinas Perindustrian dan Perdagangan Kota Pekanbaru dalam melakukan pengawasan terhadap toko modern, Disperindag tidak memiliki SOP yang jelas sehingga untuk jadwal masih dilakukan secara kondisional/tidak menentu terkait Izin Usaha Toko Modern (IUTM) begitu juga untuk personil pengawas juga tidak ada penetapan secara jelas, hanya menurunkan pegawai dinas pada bidang perdagangan secara accidental ketika dibuuhkan saja. Pengawasan biasanya hanya dilakukan keika ada pemilik usaha yang baru saja mendaftarkan nama tokonya untuk mendapatkan Izin Usaha Toko Modern dan tidak dilakukan secara berkala.

Berdasarkan dari observasi dan wawancara di lapangan dapat peneliti simpulkan pelaksanaan pengawasan terhadap kelompok sasaran dalam implementasi Peraturan Daerah Kota Pekanbaru No 09 Tahun 2014 sejauh ini masih belum optimal.Lemahnya pengawasan yang dilakukan menunjukkan bahwa upaya untuk mewujudkan tujuan dari kebijakan tersebut tidak berjalan secara efektif. Hal tersebut ditunjukkan dengan intensitas pengawasan yang dilakukan selama ini hanya dilakukan 1 (tiga) kali ketika sebuah toko modern baru saja mendaftarkan nama usaha dan tidak dilakukan secara berkala. Upaya pengawasan yang telah dilakukan juga belum merata ke seluruh wilayah Kota Pekanbaru sehingga masih banyak celah yang dimiliki oleh pelaku usaha toko modern untuk mengoperasikan toko swalayannya diluar ketentuan yang telah diatur.Selain itu, pelaksanaan pengawasan terhadap aktivitas toko swalayan hingga saat ini tidak memiliki jadwal rutin yang ditetapkan dan juga mekanisme pengawasan belum diatur secara jelas dan rinci tercantum dalam suatu petunjuk teknis atau SOP berlaku sehingga tidak terstruktur dengan baik.

\section{B. Tindakan terhadap toko yang melanggar}

Perda Kota Pekanbaru No 09 Tahun 2014 dalam pelaksanaannya, Disperindag, DPMPTSP dan Satpol-PP menjadi instansi resmi yang bertugas melakukan penindakan terhadap toko yang melanggar aturan yang terdapat pada tiap-tiap pasal di Perda tersebut. Baik toko yang melanggar aturan kebijakan zonasi, kebijakan perizinan maupun kebijakan waktu operasional.

Dari hasil wawancara yang dilakukan peneliti bersama Dinas Perdagangan dan Perindustrian Kota Pekanbaru dalam melakukan pengawasan ke lapangan jika mendapati suatu toko berdiri tanpa izin lengkap maka tidak langsung melakukan penyegelan melainkan memberikan Surat Peringatan (SP) pertama terlebih dahulu pada pelaku usaha toko modern. Kemudian setelah dilayangkannya surat peringatan tersebut kemudian toko diminta untuk mengurus surat menyurat mengenai perizinan yang harus dimiliki yaitu tentumya Izin Usaha Toko Modern (IUTM) tersebut.

Berdasarkan wawancara dan obervasi di lapangan, tindakan pemerintah terhadap toko yang melanggar sejauh ini belum optimal dikarenakan sanksi yang diberikan masih tidak dapat membuat kelompok sasaran menjadi patuh pada peraturan tersebut. Sanksi sebagai instrumen dalam penegakan peraturan yang diberikan kepada pelanggar bertujuan agar memberikan efek jera sehingga pelanggar tidak akan mengulangi kesalahannya. Namun, sejauh ini sanksi yang diberikan kepada pelanggar Perda Kota Pekanbaru No 09 Tahun 2014 masih sebatas pemberian surat peringatan (SP). Pemberian sanksi berupa surat peringatan tersebut tidak menimbulkan efek jera bagi toko swalayan modern yang pernah melakukan pelanggaran sementara poin pelanggaran yang dilakukan sudah jelas melanggar Perda yang berlaku. Hal ini ditunjukkan dengan masih tetap beroperasinya toko swalayan diluar ketentuan yang ditetapkan meskipun toko swalayan tersebut pernah diberikan sanksi oleh Dinas Perdagangan dan Perindustrian Kota Pekanbaru. Ketiadaan efek jera yang ditimbulkan menyebabkan pelanggaranpelanggaran yang dilakukan oleh pelaku usaha toko swalayan menjadi hal yang tidak ditakuti sehingga kondisi yang ingin dituju oleh kebijakan tidak akan dapat terwujud.

Berdasarkan uraian diatas, dapat disimpulkan bahwa untuk indikator Tingkat Kelancaran Rutinitas masih belum berjalan optimal karena dinilai dari 2 sub indikator yang ada yakni Pelaksanaan pengawasan 
dan tindakan terhadap toko yang melanggar dikarenakan tingkat pengawasan oleh pemerintah yang masih lemah dan sanksi yang diberikan dinilai tidak tegas sehingga tidak memberikan efek jera.

\subsection{Implementasi Peraturan Daerah Kota Pekanbaru Nomor 9 Tahun 2014 dinilai dari Variabel Tingkat Keberhasilan Dampak/Tujuan}

Penegakan kebijakan yang efektif, tentunya mampu merubah perilaku kelompok sasaran untuk dapat beraktivitas sesuai dengan peraturan yang ada dan tidak ada lagi pelanggaran yang dilakukan melalui kegiatan edukasi/pembinaan kelompok sasaran agar perilakunya sesuai dengan yang diharapkan pada tujuan kebijakan.

Adapun tujuan yang hendak dicapai oleh Perda Nomor 09 Tahun 2014 adalah terciptanya persaingan pasar yang sehat, adapun langkah menciptakan persaingan ekonomi yang seimbang adalah dengan melakukan pembinaan kepada sasaran kebijakan. Pembinaan pusat perbelanjaan dan toko modern/swalayan telah diatur dalam Peraturan Daerah Kota Pekanbaru Nomor 09 Tahun 2014 tentang Pengelolaan Pasar Rakyat, Pusat Perbelanjaan dan Toko Swalayan pada pasal 35 ayat (1) yang berbunyi: "Walikota melalui Dinas Perindustrian dan Perdagangan melakukan pembinaan terhadap Pusat Perbelanjaan dan Toko Swalayan. Pembinaan sebagaimana dimaksud pada ayat (1) berupa yang pertama mendorong Pusat Perbelanjaan dan Toko Swalayan untuk membina UMKM yang melakukan kemitrausahaan; dan yang kedua sosialisasi kebijakan dan peraturan perundang-undangan terkait dengan Pusat Perbelanjaan dan Toko Swalayan".

\section{Mendorong Pusat Perbelanjaan dan Toko Swalayan Untuk Melakukan Kemitraan dengan UMKM}

Kemitraan UMKM yaitu menjamin hubungan kerjasama antara usaha kecil, menengah dan besar dengan toko swalayan/modern untuk pembinaan berbentuk pengembangan UMKM seperti menyediakan tempat jualan serta kerjasama terhadap produk lokal yang dihasilkan oleh UMKM tersebut.Dalam hal ini perlu penegasan dari Pemerintah Kota yaitu Dinas Perindustrian dan Perdagangan dalam mengawasi hubungan kemitraan tersebut.

Berdasarkan hasil survei peneliti di lapangan bahwa dalam kerjasama antara toko modern dengan UMKM Kota Pekanbaru memang sudah diterapkan oleh sebagian toko modern, walaupun peneliti juga menemukan adanya masyarakat tempatan yang tidak melakukan kemitraan. Untuk proses kemitraan pihak toko modern memang mengajukan persyaratan tertentu yaitu dalam penyewaan tempat atau teras toko modern, salah satu syaratnya tidak boleh memperjualbelikan barang dagangan yang sama dengan toko modern sehingga hal inilah yang menyulitkan para pedagang kecil atau pedagang gerobak disekitarnya karena pedagang ini notabenenya menjual barang yang sama dengan usaha toko modern.

Dari hasil wawancara dan observasi peneliti di lapangan dalam melaksanakan Peraturan Daerah Nomor 09 Tahun 2014 dapat disimpulkan bahwa Disperindag dalam mengedukasi kelompok sasaran untuk melakukan kemitraan sudah berlangsung optimal, ini dibuktikan dengan telah banyak berdiri usaha UMKM di teras toko modern dan telah disediakan rak khusus untuk menampung produk lokal milik warga tempatan.

\section{Sosialisasi Kebijakan dan Peraturan Perundang-undangan Terkaitdengan Toko Modern}

Pembinaan yang ditujukan kepada Toko Modern yang dimaksud adalah dilakukannya sosialisasi kebijakan dan peraturan perundang-undangan terkait yakni Perda kota Pekanbaru No 09 Tahun 2014 yang dilakukan oleh Instansi Pemerintah yang bertugas menerbitkan perizinan yaitu Dinas Perindustrian dan Perdagangan dan Dinas Penanaman Modal dan Pelayanan Terpadu Satu Pintu (DPMPTSP). Dalam hal ini hendaknya Pemerintah terkait selalu bersinergi untuk melakukan pembinaan menyangkut hal-hal diatas supaya Peraturan yang telah dibuat bisa dijalankan dengan semestinya. 
Berdasarkan wawancara dan observasi di lapangan membuktikan bahwa pemerintah telah berusaha maksimal melakukan edukasi berupa sosialisasi dan pemberian arahan dan informasi tentang adanya Peraturan Daerah Kota Pekanbaru No 09 Tahun 2014 Tentang Pengelolaan Pusat Perbelanjaan dan Toko Swalayan yang termasuk didalamnya seperangkat aturan yang turut mengatur pendirian dan keberlangsungan operasional toko modern Indomaret dan Alfamart beserta sanksi dan tindakan yang dilakukan jika terdapat pelanggaran yang terjadi diluar dari yang diatur didalam Perda tersebut kepda sasaran kebijakan dalam hal ini adalah toko modern Indomaret dan Alfamart dengan berbagai cara agar tujuan kebijakan tersampaikan namun respon dari pihak toko modern belum maksimal dalam upaya sosialisasi tersebut.

Berdasarkan wawancara dan observasi di lapangan dapat disimpulkan bahwa untuk indikator Keberhasilan dampak/tujuan sudah berjalan cukup optimal karena dinilai dari 2 sub indikator yang ada yakni Mendorong toko modern untuk melakukan kemitraan dengan UMKM dan sosialisasi terkaitkebijakan perizinan, kebijakan waktu operasional dan kebijakan zonasi hanya sub indikator kedua yang belum berjalan optimal yakni sosialisasi terkait perundang-undangan walaupun usaha pemerintah untuk melakukan sosialisasi sudah dilakukan tetapi tidak berjalan lancar karena kurangnya kesadaran diri dari pelaku usaha untuk turut mengikuti undangan sosialisasi dan upaya dari pemerintah. Sementara untuk indikator pertama sudah berjalan cukup baik/optimal karena sesuai dengan wawancara dan observasi peneliti di lapangan bahwa toko modern indomaret dan alfamart sudah melakukan kemitraan dengan UMKM yang ada disekitar sesuai dengan yang diatur didalam Perda No 09 Tahun 2014 tentang Pengelolaan Pasar Rakyat, Pusat Perbelanjaan Dan Toko Swalayan.

Berdasarkan uraian diatas, peneliti dapat menarik kesimpulan bahwa Implementasi Kebijakan Perda kota Pekanbaru No 09 Tahun 2014 tentang pengelolaan pasar rakyat, pusat perbelanjaan dan toko swalayan (studi kasus Indomaret dan Alfamart) di kota Pekanbaru belum berjalan optimal. Dinilai dari indikator pertama tingkat kepatuhan kelompok sasaran belum berjalan optimal.Indikator kedua tingkat kelancaran rutinitas belum berjalan optimal.Sementara indikator ketiga yakni keberhasilan Dampak/Tujuan sudah berlangsung cukup optimal.

\subsection{Faktor-faktor Penghambat Implementasi Kebijakan Perda KotaPekanbaru No 09 Tahun 2014}

Berdasarkan observasi dan wawancara yang peneliti lakukan dilapangan, adapun faktor-faktor penghambat dalam Implementasi Kebijakan Perda No 09 Tahun 2014 tentang pengelolaan pasar rakyat, pusat perbelanjaan dan toko swalayan (Studi kasus Indomaret dan Alfamart) di Kota Pekanbaru adalah sebagai berikut:

\section{Sumber Daya Manusia (SDM)}

Dalam pelaksanaan Pengawasan Izin Usaha Toko Modern (IUTM) oleh Dinas Perdagangan dan Perindustrian Kota Pekanbaru (Studi kasus ritel Alfamart dan Indomaret) yang menjadi salah satu hambatan adalah Sumber Daya Manusia, pelaksanaan pengawasan Izin Usaha Toko Modern dapat dilaksanakan dengan optimal dan apabila didukung oleh ketersediaan SDM yang cukup dan memadai.

Dengan SDM yang memadai itu tentunya dapat menghasilkan pengawasan yang bersinergi bagi instansi terkait, dalam hal ini adalah Dinas Perdagangan dan Perindustrian Kota Pekanbaru.Sumber Daya Manusia dalam pelaksanaan kegiatan pengawasan ini adalah jumlah petugas yang melaksanakan pengawasan terhadap Izin Usaha Toko Modern yang harus dimiliki oleh seluruh toko modern yang berdiri di Kota Pekanbaru. Dalam hal ini petugas lapangan pada bidang Perdagangan dari Dinas Perdagangan dan Perindustrian Kota Pekanbaru dinilai kurang, mengingat bahwa jumlah toko modern Alfamart dan Indomaret yang ada di Kota Pekanbaru sangat banyak dan tersebar di 12 Kecamatan yang ada di Kota Pekanbaru. 


\section{Koordinasi}

Koordinasi dalam suatu pengawasan dinilai perlu dilakukan karena memang mampu untuk menjamin sinkronisasi antara kinerja aktual dengan kinerja yang di standarkan.Dengan adanya koordinasi yang baik antara instansi terkait pengawasan Izin Usaha Toko Modern ini diharapkan terlaksana dengan optimal. Dalam hal ini peneliti melihat koordinasi antara Dinas Perindustrian dan Perdagangan (Disperindag) kota Pekanbaru, Dinas Penanaman Modal dan Pelayanan Terpadu Satu Pintu (DPMPTSP) Kota Pekanbaru serta Satuan Polisi Pamong Praja (SATPOL-PP) Kota Pekanbaru dinilai belum berjalan dengan baik.

Koordinasi antara instansi pemerintah terkait yang dimaksud dapat berupa pemberitahuan pengawasan dari Dinas Perdagangan dan Perindustrian Kota Pekanbaru kepada Dinas Penanaman Modal dan Pelayananan Terpadu Satu Pintu Kota Pekanbaru serta Satpol PP Kota Pekanbaru.Sehingga pengawasan dapat berjalan optimal.

\section{Partisipasi Pelaku Usaha}

Partisipasi pelaku usaha merupakan faktor yang yang tidak kalah penting dalam menentukan berhasil tidaknya suatu kegiatan. Dalam hal ini pelaku usaha seharusnya ikut berpartisipasi dalam menjalankan aturan yang ada di Kota Pekanbaru, dimana setiap usaha toko modern seperti ritel Alfamart dan Indomaret secara hariah menjadi sasaran dari kebijjakan yang seharusnya turut patuh terhadap kebijakan yang ada antara lain seperti kewajiban memiliki Izin Usaha Toko Modern (IUTM), kewajiban mendirikan toko sesuai dengan jarak yang ditetapkan dan kewajiban menaati jam operasional sesuai dengan Perda No 09 Tahun 2014 tentang Pengelolaan Pasar Rakyat, Pusat Perbelanjaan dan Toko Sawalayan.

Pelaku usaha ritel Alfamart dan Indomaret baik perusahaan maupun pribadi ini perlu memiliki kesadaran dalam memahami dan mematuhi peraturan yang ada, dan juga perlu memahami bagaimana dampak yang terjadi jika pelaku usaha melakukan pelanggaran kebijakan. Meskipun pengawasan telah dilaksanakan oleh instansi pemerintah yang memiliki kecakapan dan keahlian dibidangnya, namun jika kesadaran pelaku usaha yang kurang untuk dapat mematuhi sebuah peraturan maka pelaksanaan kebijakan tidak akan berjalan optimal dan tujuan yang ditetapkan didalam perda tidak akan bisa tercapai.

\section{KESIMPULAN}

Dinilai dari indikator yang didasarkan pada teori Implementasi kebijakan Ripley dan Franklin dapat ditarik kesimpulan bahwa :

1) Tingkat Kepatuhan Kelompok Sasaran masih belum berjalan optimal karena dinilai dari 3 sub indikator yang ada yakni kebijakan perizinan, kebijakan zonasi dan kebijakan waktu operasional masih terdapat toko modern yang belum menerapkan kebijakan-kebijakan tersebut sesuai dengan yang diatur didalam Perda No 09 Tahun 2014 tentang Pengelolaan Pasar Rakyat, Pusat Perbelanjaan Dan Toko Swalayan.

2) Tingkat Kelancaran Rutinitas masih belum berjalan optimal karena dinilai dari 2 sub indikator yang ada yakni Pelaksanaan pengawasan dan tindakan terhadap toko yang melanggar dikarenakan tingkat pengawasan oleh pemerintah yang masih lemah dan sanksi yang diberikan dinilai tidak tegas sehingga tidak memberikan efek jera.

3) Keberhasilan dampak/tujuan sudah berjalan cukup optimal karena dinilai dari 2 sub indikator yang ada yakni toko modern sudah melakukan kemitraan dengan UMKM sedangkan sosialisasi terkaitkebijakan perizinan, kebijakan waktu operasional dan kebijakan zonasi belum berjalan optimal karena kurangnya kesadaran diri pelaku usaha untuk turut mengikuti undangan sosialisasi dan upaya dari pemerintah dalam mencapai tujuan perda.

Adapun faktor-faktor penghambat dalam implementasi Perda No 09 Tahun 2014 tentang 
Pengelolaan Pasar Rakyat, Pusat Perbelanjaan Dan Toko Swalayan terdiri dari:

1) Sumber Daya Manusia

2) Koordinasi, dan

3) Partisipasi Pelaku Usaha.

\section{SARAN}

Terdapat beberapa saran dari peneliti untuk pihak yang terlibat langsung dalam pelaksanaan Perda No 09 Tahun 2014 tentang Pengelolaan Pasar Rakyat, Pusat Perbelanjaan Dan Toko Swalayan. Di kota Pekanbaru seperti Dinas Perindustrian dan Perdagangan kota Pekanbaru, Dinas Pelayanan Perizinan dan PenanamanModal Terpadu Satu Pintu (DPMPTSP) Kota Pekanbaru yaitu:

1. Dalam pelaksanaan Pengawasan Izin Usaha Toko Modern (IUTM) oleh Dinas Perdagangan dan Perindustrian Kota Pekanbaru (Studi kasus ritel Alfamart dan Indomaret) upaya yang perlu dipertimbangkan oleh Dinas Perdagangan dan Perindutrian Kota Pekanbaru ialah dengan menambah personil khusus untuk mengawasi Izin Usaha Toko Modern (IUTM) serta melakukan pengawasan rutin untuk meminimalisir terjadinya penyimpangan di lapangan.

2. Dinas Perdagangan dan Perindustrian Kota Pekanbaru sebaiknya bisa membangun koordinasi yang baik dengan DPMPTSP Kota Pekanbaru serta Satpol PP Kota Pekanbaru dengan melakukan pengawasan bersama secara berkala dan melakukan penindakan secara tegas dengan memberikan sanksi yang memberikan efek jera terhadap gerai Alfamart dan Indomaret di kota Pekanbaru yang melakukan pelanggaran.

3. Kepada pemilik usaha toko modern ritel Alfamart dan ritel Indomaret agar meningkatkan kesadaran untuk dapat patuh terhadap kebijakan perizinan yakni mengurus IUTM sebelum mendirikan toko modern, mematuhi kebijakan zonasi yakni memperhatikan jarak dengan pedagang tradisional dan pelaku UKM sekitar minimal 350 meter dari toko modern, dan diharapkan toko modern dapat mematuhi kebijakan sesuai dengan Peraturan Daerah No 09 Tahun 2014. 


\section{DAFTAR PUSTAKA}

[1] Creswell, J. W (2010). Research design: pendekatan kualitatif, kuantitatif, dan mixed. Yogjakarta: PT Pustaka Pelajar

[2] Leo, Agus(2014). Politik Lokal dan Otonomi Daerah. Bandung: Alfabeta

[3] Mahmudi. (2013). Manajemen Kinerja SektorPublik Edisi Revisi. Yogyakarta: Unit Penerbit dan Percetakan STIM YKPN

[4] Nugroho D, Riant (2013). Metode Penelitian Kebijakan. Yogyakarta : Pustaka Belajar

[5] Peraturan Daerah Kota Pekanbaru Nomor 9 Tahun 2014 tentang pengelolaan pasar rakyat, pusat perbelanjaan dan toko swalayan

[6] Sugiyono(2010). Metode Penelitian Pendidikan Pendekatan Kuantitatif, kualitatif, dan R\&D. Bandung: Alfabeta.

[7] Winarno, Budi (2012). Kebijakan Publik, Teori, Proses dan Studi Kasus. Cet I, Yogyakarta: CAPS 